\title{
Hegelian Dialectics: Implications for Violence and Peace in Nigeria
}

\author{
Francis Etim, Maurice Kufre-Abasi Akpabio \\ Department of Philosophy, University of Uyo, Uyo, Nigeria \\ Email: Etimfrank@yahoo.com
}

How to cite this paper: Etim, F., \& Akpabio, M. K.-A. (2018). Hegelian Dialectics: Implications for Violence and Peace in Nigeria. Open Journal of Philosophy, 8, 530-548.

https://doi.org/10.4236/ojpp.2018.85037

Received: August 1, 2017

Accepted: November 16, 2018

Published: November 19, 2018

Copyright $\odot 2018$ by authors and Scientific Research Publishing Inc. This work is licensed under the Creative Commons Attribution International License (CC BY 4.0).

http://creativecommons.org/licenses/by/4.0/

(c) (i) Open Access

\begin{abstract}
"Life is a mystery" is a saying that most people are familiar with. The mysteriousness of life consists, among other things, in its unpredictability despite efforts and developments in science and technology. Indeed paradoxes and contradictions abound in every facet of life to an extent that some would be inclined to subscribe to nihilism, fatalism or catastrophism as the primordial reality. This is implied in Heraclitian "flux", the dialectic of Hegel, the "nothingness" of Sartre, etc. The logical implication of these positions would be the meaninglessness of life. But is life really meaningless? Can something positive come out of the negative events in the world like violence, conflict and war and so on? Could the myriads of violence in Nigeria, for instance, caused by Boko Haram in the North East, in the East by Indigenous People of Biafra (IPOS) and in South-South by Niger Delta Avengers be beneficial in the long run? In other words, could something positive be ensued from these obnoxious situations? These are the concern of this paper which examines the Hegelian dialectics that apparently accepts the co-existence of paradoxes and contradictions as complementary realities resulting in a synthesis. However, this paper believes that the synthesis will only lead to a better state of affairs if premised on affective humanism as an ontology.
\end{abstract}

\section{Keywords}

Hegel, Dialectics, Violence, Peace, Affective Humanism, Boko Haram, Niger Delta Avengers, Indigenous People of Biafra (IPOB)

\section{Prolegomena}

There is a famous saying among Nigerians that "life is full of ups and down". The reality of the saying is so glaring that it has become an axiom. Daily events ${ }^{1}$ This saying is part of the traditional sapiential sayings that is traceable to an anonymous ancestor or author. 
in the world from time till today exhibit this complementary nature of existence to such an extent that some are inclined to think of complementarity as an ontology. This was the position of Heraclitus who saw "change" as the arche-type of reality and Hegel who believed that "contradictions, tensions, paradoxes, oppositions and reversals are at the heart of all thought and even realty itself" (Lawhead, 2002). The Africans too believe in complementarity of opposites. Given this scenario, there is a tendency in nihilistic mind to see disaster in the world order. Some would be fast to toe or emphasize either side of the divide as fundamental and absolute. Hegel, however, following his dialectic insists that "truth is multifaceted and each set of oppositions points to higher, more encompassing viewpoints" (Lawhead, 2002). It is within this understanding that violence that is usually regarded as an unpleasant phenomenon; a state of affair with devastating consequences to the political, social, religious and economic life of a people and a nation, which is undeniably part and parcel of the world order is examined in this paper.

World Health Organization defines violence as behaviour or treatment in which physical force is exerted for the purpose of causing damage (Wikipedia, Online). The noun form means behaviour involving physical force intended to hurt, damage, or kill someone or something with brutality, strength of emotion or of destructive natural force portraying its intensity and severity (Oxford Dictionary, Online). The verb, "violent" means to be incompatible or at variance; it is a clash, understood as an act of aggression, with the property of being wild or turbulent, a turbulent state resulting in injuries and destruction; intentional use of physical force or power, to threaten or cause damage. Conflict, on the other hand, though not of ferocious nature like violence, is a serious disagreement or argument, typically protracted dispute, quarrel, squabble; to come to collision or disagreement: be contradictory; active disagreement between people with opposing opinions. It differs from violence in magnitude, intensity and effect. Sometimes, protracted conflict escalates into violence (Wikipedia, Online). Heraclitus who is accredited with being the first to articulate this thought on violence as the basis of reality used the word eris which has many connotations to describe conflict and strife. It could stand for war, quarrel, debate, rivalry, contention, jealousy, etc. So, this paper employs violence and conflict inter-changeably as an unpalatable situation of turbulence, internally and externally, which is often expected to results in catastrophe.

Based on this understanding of violence and given the spate of the phenomenon of violence in Nigeria, ranging from religious, ethnic to political, with magnitude far beyond any expectation and anticipation, and taking varied dimensions and configurations from domestic to public strikes and agitations and now terrorism, many would be fast to paint a gloomy picture for Nigeria's future. However, based on Hegel's dialectic that subscribes to complementarity of opposites, this paper examines violence and strife in its ontological perspective in order to find out its intrinsic worth as a complement of peace. Again, given the fact that there is no nation without some form of rancor, the paper then inquires 
into the necessity of such a phenomenon in the development of a nation like Nigeria with myriads of other contending problems like underdevelopment, poverty, corruption, ineffective leadership, unpatriotic citizens, poor educational system, and mal-administration and so on. In other words, this paper seeks to find out if violence of any kind and magnitude can be of any benefit to any country at all talk less of a developing nation like Nigeria? This is the kernel of this paper.

\section{The Nigerian Situation}

To say that Nigeria, as a nation, has had its fair share of violence and conflict is to state the obvious (C.f. Olawale (2018), ynaija.com; Akinnaso (2018), punching.com: O'Grady (2018), The Washington Post). There is so much violence and conflict in Nigeria beginning form the home to the public sphere, from the secular to the preserved sphere of religion, with unprecedented frequency, velocity and tenacity that many are afraid of their consequences to Nigeria's fragile nationhood. Of recent, the activities of Boko Haram in the North East, Herdsmen and farmers clashes in the Middle Belt, the Independent People of Biafra (IPOS) in the East and the Niger Delta Avengers in South-South have posed serious threat to Nigeria's nationhood and should usually be a cause for concern to any serious minded person. The issue of violence, however, is not limited to Nigeria as the world in general has had a fair share of it. Even countries in Europe and United States of America that could be said to have all it takes to contend it have become its prey in recent times not to mention the Middle East that is almost becoming a theatre of war.

However, the violence in each country and continent has its peculiarities which could account for it causa generi. In Nigeria, the phenomenon of violence could be attributed to so many factors. Aside from the perennial religious and political violence, there is also violence which is engendered by economic factors. For instance, cases of militia groups in the Niger Delta region of the country that emerged as a result of perceived neglect, injustice and destruction of their environment and the nomadic Fulani herdsmen over grazing areas for their cattle, which have resulted in many deaths, kidnapping, rape and various forms of violence in Plateau state, Benue state, Enugu state, etc.

Besides, violence in the public sphere there are conflicts and violence in the homes. Cases of chieftaincy tussle, communal land clashes, family in-fighting abound everywhere. The country is then largely mired in a cesspool of conflicts that threaten her very survival as a nation. Every day the country makes news headlines on various forms of violence, reflecting the Hobbesian state of nature. Conflict is almost becoming the order of the day to such an extent that people are becoming familiar with sights of violence. They are inundated with news of violence on daily basis such that they may regard the problem as insurmountable. But is the situation unredeemable? Certainly, not so as every human problem can be solved given the right approach and appreciation of the problem. It is on this note that a consideration of Hegelian dialectics of violence is contem- 
plated as another perspective to the issue of violence in Nigeria and the world over.

\section{Violence as an Ontological Phenomenon}

Heraclitus' position seems to suggest violence as constitutive of reality when he conceived everything as being in a state of flux-change. To him, what constitutes the essence of the world, that sets it in constant motion, is fire; which is also a principle of war (Polemos) and strife (Eris). He saw conflict of opposites as the very essence of reality and the condition for change. Explaining Heraclitus' position, Stumpf puts it thus:

The conflict of opposites is not a calamity but the permanent condition of all things. If we could visualize the whole process of change, we should know, says Heraclitus that "war is common and justice is strife and that all things happen by strife and necessity". From this perspective, he (Heraclitus) says, "what is in opposition is in concert, and from what differs comes the most beautiful harmony". Even death is no longer a calamity, for, "after death things await men which they do not expect or imagine" (Stumpf, 1971).

For Heraclitus, then, what constitutes the world is conflict, which should not be necessarily viewed and taken as negative, but as the very condition that engender change and progress; even when it may momentarily seem to be quite the opposite. This underscores the fact that the world is the unity of diversity which Heraclitus originally rendered in Greek as sumpheromenon diapheromenon.

This position is supported by William Abraham (1985) who submits that though the world seems to be orderly or an ordered whole, it is also a theatre of conflicts and inherent disorderliness that defies human logic and permutation. In his words:

The intended orderliness of nature is not to be grasped as a sheer datum-this much has been apprehend in the felt intractability and existential distress begotten of it, intractability which may occasion unexpected famine through blight, and physical destruction, through sudden flood, earthquake, or spontaneous conflagration.

Even in the world of science, it is a generally accepted thesis that the world itself came to be through a violent process: the Big Bang Theory. The theory is explained by Encarta thus:

The Big Bang theory proposes that the universe was once extremely compact, dense, and hot. Some original event, a cosmic explosion called the big bang, occurred about 13.7 billion years ago, and the universe has since been expanding and cooling (Encarta Online (2013), www.world-mysteries.com).

Consequently, science sees the world as a product of violence. This original conflict that gave birth to the universe, which include the totality of existence, makes conflict an ontological phenomenon that undergirds all of reality thus 
nothing escapes its provinciality. Little wonder our world and indeed the universe, is home to so many natural violent irruptions like earthquakes, tsunamis, tidal waves, landslides, volcanic eruptions, gales, hurricanes, etc., all of which man cannot do anything about, in spite of his technological breakthroughs. It is, therefore, all too apparent that violence is an ontological phenomenon that is hardwired even into nature itself and the whole gamut of existence.

Even the human nature itself is embedded in the factuality of conflict and is largely defined by it, as the psychologists would make us believe. For instance, the foremost psychologist, Karl Jung, saw the human mind as the interplay of many opposing impulses that regulate it and ensure equilibrium. According to him, when a certain impulse or libido reaches its extreme, it passes into its opposite (Fordham, 1966). This means that the human psyche is so made that it is a theatre of constant conflict between the various impulses.

The ontological reality of conflict made Thomas Hobbes, in the Leviathan, to paint human nature in its original state (the state of nature) as being characterized by violence. In Hobbes words:

During the time men lived without a common power to keep them all in awe, they are in that condition which is called war; and such a war, as is of every man, against every man (cited by Alexander Moseley, 2015).

In fact, contrary to Hobbes position, even the presence of the Leviathan that was to keep the people in awe could not take away conflicts from the human society. This is because conflict is inherent in the human reality as a condition of its being, as such. This fact is well supported by Fyodor Dostoyevsky (1957) in Brothers Karamazov.

In every man, of course, a beast lies hidden-the beast of rage, the beast of lustful heat at the screams of the tortured victim, the beast of lawlessness let off chain, the beast of diseases that follow on vice, gout, kidney disease, and so on (ii, v.4).

Given the above supposition, violence and conflict, then could readily be regarded as an ontological phenomenon that is predicated on the supposition of change as a primordial reality. Such position, of course has a lot of metaphysical implications as highlighted by Parmenides position of permanence as the basis of reality. If granted that eris and polemos are the fundamental realities then what ensues today as misunderstanding, quarrels, discord, rebellion, disputes, contradiction, debate, argument etc, are natural consequences.

However, given the negativity often associated with these phenomena, it seems really absurd that something positive could be derived from them. Hegel in his dialectic, on the contrary, maintains that opposite terms and categories could be deduced from each other. For him, things always dissolve into their opposites. From painful and violent situations emerge desirable outcomes. For instance, forests have to be destroyed in order for towns and wonderful structures to emerge; the soil has to be tilled and violently worked on in order for 
things to be planted; even planted things have to decay before they can germinate and produce the required fruits and so on. This realization must have informed the adage that "if you want peace, gets ready for war".

The dialectics of violence and peace is often a celebrated theme in religion. For example, in Christian and Jewish theology, it is opined that the world was created from the nebulous and amorphous state of uncertainty as could be gleaned from the Genesis account of creation that; “... the earth was a formless void, there was darkness over the deep" (Gen. 1: 1-2). It was also after the violence and tumult of the floods during the time of Noah that a New World emerged that was characterized by peace and abundance (Gen: $6 \& 9$ ). Even the salvation of man, according to Christian theology was wrought through persecution, suffering, death and eventual resurrection of Jesus Christ.

This dialectic seems to be anchored on the fact of duality of existence which is typified in instances like day and night, hot and cold, man and woman, young and old, being and non-being, good and evil and so on. Dialectically, these apparently opposite realities are believed to be dissoluble into each other as complements and so could be regarded as mutually inclusive. Corollary, violence could be regarded as mutually inclusive of peace, without which peace would not be achieved and valued. This bent of thinking must have informed Franz Fanon's (1967) observation that "... human reality in-itself-for-itself can be achieved through conflict and through the risk that conflict implies".

What this translates to is that violence and peace are deducible from each other. The very idea of violence brings to mind the idea of peace and vice versa. Peace is seen as the absence of violence, and violence as the absence of peace. Thus, even in the conceptual analysis of the two terms, they are implicated in each other. Each makes sense in the context of the absence of the other, as Being and Nothing in the Hegelian dialectics. The absence of one makes the presence of the other inevitable, which shows a binding and ontological-cum-dialectical relationship. Though David Hume would have picked fault with this position on the ground that there is no constant conjunction between the two to prove a necessary connection that necessarily imply their co-existence. However, the traditional criticisms against Hume's ultra skepticism hold here, mutatis mutandis. That the necessary connection cannot be empirically given does not imply that there is no logical and ontological relationship between violence and peace.

This position would naturally evoke some fundamental question regarding the nature of violence. Is violence intrinsically bad? Can something good be derived from something that is bad? Can violence be justified generally or in some circumstances?

\section{Hegel's Dialectics}

Hegel is one of the contemporary philosophers with a rationalistic bent of mind. He was greatly influenced, among others, by the ancient Greek philosophers like Socrates, Aristotle and the rest. Among the thoughts of the ancient that so fasci- 
nated him was dialectic. Dialectic as used by Socrates was a formal system of reasoning to midwife truth from people especially the Sophists. In this method usually took the pattern of discussion between two seekers of truth on a topic where diametrically opposed points of view may be advanced at first instance. As the argument ensues, both parties may gradually come to understand each other's position and both may come to agree or to reject their own earlier partial view for a broader view. In this case, the original opposition has been reconciled in higher synthesis. It was this Greek's usage of dialectic that led Hegel to the discovery of the relationship between Logic, Nature and Mind. Hegel then conceived this relationship as resulting in a cyclic procedure characterized as thesis (the positive side), the antithesis (the Negative side) and the synthesis (the product). For Hegel, the synthesis itself would become another thesis, and thereby repeating the triadic dialectical process all over, till its culmination in the Absolute.

The dialectics of Hegel, which serves as the methodological tool of his philosophical system, is embedded in his logic. Hegel's idea of logic is a deviation from the traditional understanding of the discipline as a tool and method of discovering the course of realities. That means, Hegel understood logic virtually as metaphysics (Stumpf, 1971). May be, he was influenced by Descartes' insistent on methodology for clearer understanding of reality. However, while Descartes was more concerned about the relations of ideas to each other, Hegel's methodology was anchored on the inner logic of the totality of reality itself. Hegel's bent of mind is explained by Stumpf (1971) as based on the fact that:

Since Hegel had identified the rational with the actual, he concluded that logic and logical connections must be discovered in the actual and not in some empty ratiocination.

To this end, Hegel's logic is not necessarily concerned with the relations of abstract categories but concerned with the categories and facts of experience as well as those of abstract terms. So, he applied it to the totality of existence.

In a nutshell, the crux of Hegelian logic entails that nothing can be deduced from nothing which, however, was a repeat of the well-known principle in formal logic that preceded Hegel. In formal logic, it is taken that the conclusion must always be contained in the premise. There is no category that can be deduced from another category that is not implicit in that category. Thus, one cannot deduce B from A if B was not already in some way contained in A. In formal logic, the species are always deduced from the genus. In this way, for instance, the specie, man, is deduced from the genus animal. This is what Spinoza meant earlier as all determinations are negations. It is the determination of the species that negates them from the genus and other species of the self same genus. The genus, as a pure concept, is indeterminate and undifferentiated. So it is the instance, of say, a goat that differentiates it from man though both come from the same genus, animal.

The issue, however, is that if both are different by virtue of their specific de- 
terminations, for instance, man and goat, though of one genus, are their specific determinations deducible from the same genus? For instance, can man be deducible from animal. This has always been a dilemma in formal logic: whether what differentiate(s) the species of a particular genus could be deduced from the genus itself. This problem is better appreciated when one fully grasps the meaning of a genus or universal. A genus is a general idea from which particular things share in common. But, as a general idea, the genus contains no specific characteristics-were it to be so, it will be a certain thing whose characteristics it possesses and no longer a universal pure concept. What differentiates the species of a particular genus is the differentia.

The novelty of Hegel's position lies in his attempt to show that the differentia could be deduced from the genus. According to W. Stace (1955):

The solution of this problem constitutes the central principle of Hegelian philosophy, the famous dialectical process. It rests upon the discovery that it is not true, as hitherto supposed that a universal absolutely excludes the differentia. Hegel found that a concept may contain its own opposite hidden away within itself, and that this opposite may be extricated or deduced from it and made to do the work of a differentia, thus converting genus into species.

Herein, lies the crux of the Hegelian dialectics that opposites are deducible from each other in order to form a third category, becoming. Hegel conceived the dialectical process as a triad, thesis, antithesis and synthesis, though he never employed these terms in his system. He rather used the terms Abstract, Negation and Concrete, to stand for thesis, antithesis and synthesis respectively.

To demonstrate his dialectics, Hegel started with the most abstract and general idea that the mind can possibly form-Being, as the thesis. What informed his choice of Being as the first thesis was his belief that the mind or thought moves from the most abstract idea to specific and concrete ones. For him, therefore, the most general idea the mind can possibly conceive is Being, which by itself is logically prior to any determination and differentiation. Logic therefore has to begin with the indeterminate concept of pure Being, which is the general featurelessness that precedes all definite character and is the very first of all (Stumpf, 1971).

The onus on Hegel (1999) was to show that anything could be deduced from the concept of pure Being. He described pure being as:

... equal to itself. It is also unequal relatively to another; it has no diversity within itself nor any with a reference outwards...simply equality with itself, complete emptiness, absence of all determination and content.

From the standpoint of formal logic, following the principles of identity and excluded middle, a thing is what it is and nothing else. But Hegel thought it otherwise. He held that something new could be deduced from a universal term, which Aristotle and other formal logicians had deemed impossible. 
Hegel strongly believed that a universal term contains some other category that could be deduced from it. To demonstrate this, he analyzed the concept of pure Being. According to him, the idea of pure Being is abstract and indeterminate; it contains no particular qualities, since if it did it will no longer be pure Being. But the very fact that it contains nothing and lacks determination makes the idea of pure Being negative. Since it contains nothing, it is also akin to not-being. There is virtually no difference between pure Being and Nothing; both could be deduced from each other. This really sounds absurd, a fact Hegel himself acknowledged when he said that "the idea that Being and Nothing are the same is so paradoxical to the imagination or understanding that it is perhaps taken for a joke" (Stumpf, 1971). Although, he saw the incredibility of the above proposition, Hegel went ahead to maintain that the idea of pure Being contains Nothing, therefore Nothing itself could be deduced from pure Being. Put symbolically, the universal A, as a category, contains a not A (-A).

The above is the main outline of Hegel's logic and dialectics that the opposites, rather than being mutually exclusive, are implicated in each other. Thus, the concept of Being, as a thesis, necessarily contains its opposite-Nothing, as its antithesis and are deducible from each other. This opposition, according to Hegel, creates a third category, Becoming. This third category implies the union or synthesis of Pure Being and Nothing. David James (2007) throws more light on this thus:

Hegel's attempt to preserve the distinction between Being and Nothing is to be found in his concept of Becoming., which, when analyzed, turns out to contain within itself both Being and Nothing, either as coming-to-be, in which case thought moves from Nothing to Being, or as ceasing-to-be, in which case thought moves from Being to Nothing.

Becoming, then, implies the synthesis of Being and its antithesis, Nothing. Hegel saw Being and Nothing as distinct moments, but which nevertheless are mutually involved in each other. Becoming only is, in so far as they are distinguished. The third is the other than they; they subsist only in the other, which is equivalent to saying that they are not self-subsistent (Hegel, 1999).

Interestingly, Hegel did not stop at the level of Pure Being in his dialectics, but applied it to the whole of existence as the principle that undergirds everything. For him, everything in the world exhibits this triadic process of the dialectics till its culmination in the Absolute.

\section{Hegel on Violence}

Hegel's thought on violence is a corollary of his dialectic. Obviously, the role violence plays in bringing something new into the universe was not originated by Hegel in his dialectics, but had been mooted years before Hegel was born by Heraclitus in the ancient period. Heraclitus whose thoughts, no doubt, greatly influenced Hegel, saw the dialectical importance of violence, strife or war as a precursor to something new and positive when he stated in Fragment 56 that 
"war is the Father of all and King of all, and some he shows as gods, others as men; some he makes slaves, others free" (Hegel, 1880). As noted earlier, the original Greek word Heraclitus used was Eris, which has many connotations. It could stand for war, quarrel, debate, rivalry, contention, jealousy etc. For Heraclitus, strife or conflict is the order of the day; nothing is certain and permanent. Everything is omnia flux-(everything changes). Since for him, no one can step into the same river twice. Therefore, for Heraclitus, violence or conflict has a purgative role and brings something new into the universe. This explains why he conceived "Fire" as the original matter, the urstuff or arche, of the universe.

Explaining Heraclitus position, Nicholas of Cusa maintains that finite things are locked in perpetual conflict with each other as contraries, and are always at pains to erase each other from existence. This conflict goes on eternally and would have brought chaos into the world, safe for the fact of reason (Ratio), which mediates these conflicts among opposing things, thus ensuring balance in existence. This he refers to as synthesis of opposites-coincidentia oppositorum (Oburota, 2000). Such contraries include essence and existence, non-being and being, greatness and smallness, more and less, one and many, etc. The bottom line of the submission of Nicholas is that there is a dialectical process in nature that ensures balance among opposing things, and that negativity experienced as conflicts, is an ontological condition of being and existence. It is a necessary condition that is a given, a sort of facticity.

This is concretized, according to Thomas Hobbes in the uncompromising violence in the political state that saw the emergence of the Leviathan as a stabilizing factor in maintain order. For Hobbes, therefore, without the threat of violence and its very actuality, the society will relapse to the pristine state of nature with its frightening prospects (Ryan, 1984). Though, Hobbes position should be viewed within the backdrop of his conception of the human nature as rebellious in se hence, the importance of the Leviathan to negate such tendencies

Hegel, in line with his dialectics, saw contradiction as a necessary condition for progress and development. This contradiction could be instantiated in wars, conflicts, violence, strife or disagreements. Hegel seemed more concerned with the ontology of violence and not its moral implication which would have placed violence on a negative perspective. This explains his exclusion of people like Napoleon Bonaparte, who he thought embodied the World Spirit, from being bound by the laws and morality of their times (Hegel, 1956). This, in a way, must have also informed Hegel justification of the atrocities carried out by Napoleon, where millions were killed, as the necessary dialectical stage that ushered in civilization in Europe.

For Hegel, conflict was a natural phenomenon; part of the immanent duality in nature, which serves a very useful purpose in the evolution and development of things and the human society. To buttress the beneficial role of violence in the natural scheme of things, Hegel (1807) presented this metaphor in the Phenomenology of the Spirit. 
The bud disappears in the bursting-forth of the blossom, and one might say the former is refuted by the latter; similarly, when the fruit appears, the blossom is shown up in its turn as a false manifestation of the plant, and the fruit now emerges as the truth of it instead. These forms are not just distinguished from another; they also supplant one another as mutually incompatible. Yet, at the same time their fluid nature makes them moments of an organic unity in which they not only do conflict, but in which each is as necessary as the other; and this necessity alone constitutes the life of the whole.

What this metaphor of Hegel shows is that everything contains its own negation which is constitutive of its ontological essence and ensures its organic wholeness. Therefore, negation as a contradiction, is always a positive process in Hegelian philosophy.

Erol (2010) gives a concise summary of Hegel's dialectics of violence as follows:

In a macro sense, conflict can be understood as a negation of the status quo and peace efforts as the negation of the conflict. The resulting product would be "the synthesis" or the new status quo which also has a further negation, and this dynamic would keep on unfolding.

To Hegel's (1956) mind, the ultimate end of conflict is the achievement of freedom which is the essence of the spirit (Philosophy of History, 17). Conflicts arise because people's worth are not recognized, thus impinging on their freedom. Thus freedom, according to him, consists of recognition. To this end, Hegel did not see war as evil, but as the very means by which the Absolute employs to achieve its aim. In the words of Wiser (1983):

... for Hegel, wars are not evil. Rather they are the necessary means by which the World-Spirit evolves, and thus they ensure the dominance of reason in history. For Hegel, the victors are always right because in His wisdom God so constructed history that the powerful and the righteous are always one and the same.

This position made Hegel disagreed with Kant on the "Theory of Perpetual Peace" among nations through the League of Nations that Kant had suggested as the arbiter between nations in times of conflicts. In Hegel's contention, nations are in the state of nature in relations to each other and will always protect their interests. He was skeptical about Kant's suggestion on the role of League of $\mathrm{Na}$ tions as could be gleaned from his submission that:

There is no praetor to judge between states; at best there may be an arbitrator or a mediator, and even he exercises his functions contingently also, i.e. in dependence on the particular wills of the disputants (Hegel, 1952).

Since matters between states cannot be objectively settled without recourse to contingent subjective interests, Hegel opined that the best way to settle disagreement between nations is through war, especially if their particular interests 
cannot be harmonized (Hegel, 1952).

Hegel's submission on violence as not intrinsically evil was later supported by other philosophers like Martin Heidegger (1956), Jean Paul Sartre (1992), Amilcar Cabral (1967), Frantz Fanon (1967), Oronto Douglas and Doife Ola (2003). Heidegger (1956), for instance, in his discussion on Polemos (the original violence or chaos) believes violence plays a necessary role in ushering something positively new. He defined the Polemos as "the conflict that prevailed prior to everything divine and human...; that first projects, and develops what had hitherto been unheard of, unsaid and unthought" (62). For Heidegger (1956), conflict is one of the necessary conditions of Being, Sein, which also becomes implicated in the being-of-things, Seinde, including the Dasein (the human reality). He believed that Polemos (conflict) gave birth to everything and continues to shape the course of existential events. It is very pellucid that Heidegger did not see violence as something negative, but as an ontological necessity that drives civilization on. This must have informed his dalliance with Nazism, which has unfortunately, remains a slur on his personality, in spite of, his insightful and lofty philosophical postulations.

Jean Paul Sartre also eulogized violence when he wrote in the preface to Frantz Fanon's book, The Wretched of the Earth (1982) that "this irrepressible violence... is man recreating himself". Sartre supported many liberation struggles like the Algerian War of independence from France, as ontological necessity that will bring about the full realization of the self in freedom. For him, violence is liberating and remains the only alternative left for the oppressed to cease the historical initiative and exist as authentic beings.

On the part of Amilcar Cabral (1967) (the revolutionist that masterminded the independence of Guinea Bissau from Portugal), informed by the dialectical interpretation of historical process as becoming, saw armed conflict as being necessary for advancement. For him, "we are not defending the armed fight... it is a violence against even our own people. But it is not our invention... it is not our cool decision; it is the requirement of history" (79). For Cabral, therefore, the historical reality itself requires violence as part of the dialectical process in order to arrive at the required synthesis of peace and freedom. Cabral held that violence is the only choice left for the colonized to regain their existential space and live as real beings. One can fully appreciate the imports of his position when one considers the dehumanizing state and treatment the Africans and others who lived through the indignity of colonization. In such a scenario, confrontation to negate the status quo was inevitable, since force has no moral sanction; whatever is taken by force, can by that same means (force), be legitimately regained (Rousseau, 1983). Counter-violence is antithetical to the original violence and will resolve into a synthesis of peace and freedom.

According to Frantz Fanon (1982), in The Wretched of the Earth, violence is the necessary condition for liberation from oppression. Indeed, it is "violence alone, violence committed by the people, violence organized and educated by its leaders that makes it possible for the masses to understand social truths and 
gives the key to them" (147). Fanon called for counter-violence as an ontological necessity in order to accentuate one's being from the state of wretchedness colonization imposes on the colonized. This explains why he never shied away from promoting liberation struggles.

Oronto Douglas and Doife Ola (2003) within the Nigerian context see a positive slant to the agitations of various militias that have meted violence and terror on the Nigerian polity. For them there is something positive and commendable about the various violent acts carried out by the different militias in the country. They view them as "civil society organizations that fight in concert with other progressive forces for liberation of all the oppressed people of the land". For them, the ethnic militancy is "a contribution to democracy and diversity".

\section{Implication for Violence and Peace in Nigeria}

In reality, conflict arises as a reaction to something. It could be injustice, oppression, neglect, corruption, underdevelopment, etc., though it could also be due to the very nature of reality itself, which is ontologically violence prone. At any rate, violence in many instances, as in liberation struggles, is aimed at righting some perceived wrongs. This was observed by Jean Paul Sartre (1992) when he observed that: "all violence presents itself as the recuperation of a right...and, reciprocally, every right inexorably contains within itself the embryo of violence" (Notebook of Ethics). Thus, conflicts arise when people perceive that they are deprived of what they may consider as their rights; some of which may rightly be due them, while in some instances such perception may be far from reality. Even when such rights are given, the inexorable law of dialectics will make such rights to negate some other people's right, whether real or misplaced, hence the continuation of the never ending cycle of violence and peace.

What the above illustrates is that conflict, though it may seem undesirable and odious, is nevertheless necessary to bring peace, justice, attention and redress in some instances.

As noted earlier, Hegel thought on violence would definitely provoke some salient and fundamental questions regarding the nature of violence. Is violence intrinsically bad? If so, can something good be derived from it? In other words can goodness be deducible from evil? If it is not intrinsically bad, can it be justified in any circumstance? Can a wrong means justify a good end? Must evil be necessarily present for peace to ensure? Given the dialectical process, will perpetual peace ever be attained? It appears that these issues are both ontological and ethical.

Hegel however does not seem to have been bothered about the moral implication of his thought on violence but was concerned about the ontological possibility of deducing peace from violence based on his dialectics. According to Stace (1955) Hegel found that a concept may contain its own opposite hidden away within itself, and that this opposite may be extricated or deduced from it and made to do the work of a differentia, thus converting genus into species. There- 
fore, deducing peace from violence as a logical and ontological reality is possible. However, such ontological or logical possibility does not translate into existential possibility as was shown in the case of Anselm's ontological argument. That being the case, Hegel's thought as harbinger of peace in life situation becomes a misnomer. On the contrary, life situations abound, all over the world and in $\mathrm{Ni}$ geria, in particular, where the actuality of violence has brought something positively new. For instance, without the uncompromising agitations, which were matched with violence by the Movement for the Emancipation of Niger Delta (MEND), it is doubtful if the Nigerian government would have been arm-twisted to increase the derivation formula in the sharing of oil revenues in the country. In Hegelian terms, the marginalization, exploitation and despoliation of the people and environment of the Niger Delta served as a thesis, which had to be dialectically negated or contradicted through conflict that called to question the original condition of injustice. Through the violence of the militants, attention of government was drawn to the plights of the people of the region which resulted in the setting up of the Ministry of Niger Delta Affairs, the Niger Delta Development Commission (NDDC) and many other mouth-watering packages for the militants as part of amnesty deal to end the insurgency.

All the conflicts in Nigeria are reactions to something, which in Hegelian reckoning makes them dialectically antithetical to the original theses that engendered them. Though the activities of some deranged groups in the country should be condemned for what they are; misguided and criminal in nature, nevertheless a dispassionate look at some of their provenance would reveal their dialectical significance. For instance, the Islamic militancy ravaging the north eastern part of the country, though masqueraded as a religious uprising, feeds on the political, social and economic polarities that define the region. With the culture of patronage that is prevalent in the region due to religious and cultural underpinnings, some people are kept permanently in the backwoods of poverty, the tallaka was, who have to depend on the crumbs from the privileged religious and political leaders. This scenario creates a disproportion in their Northern region and the country in general. Though their kiths and kins have held the greater reins of political power in the country's history, this has not translated into any improvement in the conditions of the people of the region. Thus, the arrival of Mallam Yussuf and his murderous ideology, which gave rise to the terrorist group, Boko Haram, was all that some needed to vent their anger on the powers that had marginalized them for so long. Thus, the original theses of peace and order perpetrated by those in authority for their own survival and relevance became negated by the violent acts of the group. Though one cannot rule out the fact that some of the members of Boko Haram are somewhat literate or mis-educated, the bottom line of membership is drawn from poor backgrounds, the almajiris. Some joined the group not necessarily because they love jihad and want to become martyrs of their faith, but because of the incentives offered by the Sect which make a difference between life and death for most of the impove- 
rished people in the region. Also, lack of proper education makes their minds pliable to dangerous indoctrinations which some fundamentalists are all too eager to fill in. All this boils down to neglect by those in authority. Their reactions should be seen as antithesis to the original condition of being peaceful in the face of neglect and deprivation that caused their confounding backwardness. Though, they may not be conscious of the imports of their acts as being dialectically significant, they are nevertheless the unconscious tools of communal becoming and historicity.

The emergence of Boko Haram and allied terrorist groups in the north has opened the eyes of government to the dangers of having an army of illiterate and jobless youths roaming the streets, especially in the North, where Islamic fundamentalists are on the prowl to recruit them for their blood-letting causes. Even the politicians who maintained the status quo and used the almajiris as cannon fodders to rig elections and cause violence to aid their causes, have now come to realize that they are creating some Frankensteins that may end up annihilating them. This informed the last administration of President Goodluck Jonathan to embark on establishing many almajiris schools in the North to forestall the recruitment of illiterate youths into terrorist ranks. Without the reality of Boko Haram, such schools would not have come to be, though it is the sensible thing that should have been done $a b$ initio.

It appears that Nigeria, particularly government responds and lives up to their responsibilities only when they are reminded through agitations, and most especially violent ones. The leaders tend to do the right things only when cornered by crises. To this effect, some scholars have suggested that conflicts should be deliberately created in order to bring about progress in our country. In the words of Adedotun Philips (1981):

If crises are deliberately created in particular problem areas which are carefully selected in order to maximize the short-term social inconvenience and ensure that such inconvenience affects all social groups (high and low), then government can reasonably be expected to act as swiftly, as it has done in the past (in emergency situations) to improve the efficiency and effectiveness of the services concerned. In essence, it is a strategy which attempts to temporarily bring down one sector in order to bring up and improve another sector.

Though the above suggestion by Adedotun may seem whimsical, it nevertheless captures the importance conflicts and crises play in our national evolution. Without violence, one could be taken for granted, exploited, neglected, marginalized and trampled upon by those in power. You need to accentuate your being by drawing attention to yourself through the language government here understands very well-violence, since it is also sustained by it. As an Ibibio proverb would have it; "ifod isitaha ayin eka asong mbang", which means that "a witch can never bewitch or kill the son of a mother who can make noise". Without conflicts, the much desired peace and its appurtenances will remain a mirage. 
What this boils down to is that violence by its very nature is not intrinsically evil, as would be suggested by some moralists in a dialectical process. As a necessary dialectics of peace, it is an ontological phenomenon that makes peace meaningful and appreciated. As was argued before, there are contexts which would make violence necessary and adjudged moral. The Just War Theory (Jus Bellum Iustum), for instance, which is even accepted by some moralists, cuts the ground off anyone that views violence as intrinsically evil. Therefore, violence should not be dismissed in one fell swoop as being necessarily evil and intrinsically morally abhorrent. The context, out of which, violence emerges should not be detached in its evaluation. The context determines the moral imports of violence and not its actuality, in se, per se.

What the above implies is that, while violence should be condemned and avoided in general, there are instances that make violence the inevitable option to cease the initiative of history, survival, self-worth to achieving peace and other desirable outcomes. Violence for Violence's sake can never be justified and is not what is intended here, whatsoever. Also, the violence hinted here is not limited or exhausted by armed conflict as earlier explained: it also stands for rebellion, agitation, disagreements, demonstrations, and strikes etc., which all seek to negate the status quo.

\section{Conclusion}

The ontological implication of dialectics inevitably results in eternal cyclic order, implying that the achieved peace (synthesis) eventually evolves into another thesis (in this case, violence), the question then is whether the desired perpetual peace will ever be attained. Can anything good come out violence? Hegel was not unaware of this implication as he proposed a situation where love will at a certain point in the dialectical process reconcile all conflicts. For Hegel, love is the reconciliation of opposites; the conflict situation is reconciled eternally in love. Love in his words is:

... a distinguishing of the two, who nevertheless are absolutely not distinguished for each other. The consciousness or feeling of the identity of the two-to be outside of myself and in the other this is love. I have my self-consciousness not in myself but in the other. I am satisfied and have peace with myself only in this other and I AM only because I have peace with myself; if I did not have it then I would be a contradiction that falls to pieces. This other, because it likewise exists outside itself, has its self-consciousness only in me; and both the other and I are only this consciousness of being-outside-ourselves and if our identity; we are only this intuition, feeling, and knowledge of our unity. This is love, and without knowing that love is both a distinguishing and the sublation of this distinction, one speaks emptily of it (Leifheit (2012), https://www.marxists.org/reference/archive/hegel/works/love/).

Commenting on this submission by Hegel, Peter J. Leithart (Online, 2003) 
writes:

Among the many fascinating things here is the implication that love is the prerequisite for a unified identity. Hegel says that to be a unified self, one must be at peace; but this peace comes only through the "distinguishing and sublation of distinction" that is love for another person; MY peace, my unity as a being, depends on love, the other's love for me and my love for another. This is suggestive, though Hegel doesn't exactly explain WHY this peace comes only "in the other." Perhaps it has something to do with his insight that part of my identity is my difference from the other; to say I am Peter is, at least, to say I am not Paul or George. This means that my identity and unified self-conception includes a moment of difference. But how that this difference not turn into endless "deference"? Through mutual (almost perichoretic) love.

It is only within this ambient of mutual love and concerns that actions of individuals, cooperating bodies and government particularly in Nigeria will not deliberately generate conflict by institutionalized neglect and injustice. After all, caring for one another through communal concern is an ontological reality in Africa. Going beyond oneself to the consideration of others will result in what this paper regards as affective humanism. So if affective humanism then becomes a "meta-motivation" (using Maslow's phrase) of action then conflict will totally be eliminated.

Affective humanism as a philosophy of action is premised on the African ontology of communalism and harmonious monism. African ontology hinges on a dualistic universe that is integrative and complementary. Both worlds are peopled with existents, visible and invisible respectively; hierarchically placed but complementary in existentiality. Every existent then lives in complementarity, harmoniously and integratively. Within this placement, every man needs another to live meaningfully and authentically. Since the world is the theatre of action for the realization of true self, then the other persons and things are equally important. Affective humanism does not consist in loving others as one would love himself but involves what both Maslow and Frankl call "auto-transcendence of self-transcendence". Self-transcendence denotes:

The fact that being human always points, and is directed, to something or someone, other than oneself-be it a meaning to fulfill or another to encounter. The more one forgets himself-by giving himself to a cause to serve or another person to love-the more human he is and the more he actualizes himself (Frankl, Quotes, Online).

As noted in my article, "Metaphysics of Terrorism" (Etim, 2018), no one can love except he transcends himself. This informs Frankl description of love as:

.... the only way to grasp another human being in the innermost core of his personality. No one can become fully aware of the very essence of another human being unless he loves him. By his love, he is enabled to see the es- 
sential traits and features in the beloved person; and even more, he sees that which is potential in him, which is not yet actualized but yet ought to be actualized (Quotes, Online).

That is why Hegel and Frankl see love as the ultimate goal to which man can aspire and that the salvation of man is through love. It is within this consideration of love that violence as a precursor of peace will become meaningful and not in perpetual violence and conflict.

\section{Conflicts of Interest}

The authors declare no conflicts of interest regarding the publication of this paper.

\section{References}

Abraham, W. (1985.). Sources of African Identity. In: A. Diemer (Ed.), Africa and the Problem of Its Identity: International Symposium on Culture and Identity. New York: Peter Lang.

Akinnaso, N. (2018). Causes of Violence in Nigeria.

Cabral, A. (1967). Return to the Source: Selected Speeches. New York: Monthly Review Press.

Dostoyevsky, F. (1957). Brothers Karamazov (Magarschack, D., \& Komroff, M., Trans.). New York: Penguin Classics.

Douglas, O., \& Ola, D. (2003). Nourishing Democracy, Nurturing Diversity: Ethnic Militancy as Resistance Politics in Nigeria. In T. Babalawe (Ed.), Urban Violence, Ethnic Militia and the Challenge of Democratic Consolidation in Nigeria. Lagos: Malthouse.

Encarta Online (2013). Big Bang Theory. http://www.world-mysteries.com/

Erol, E. (2010). Understanding in Conflict: A Hegelian Approach to Conflict Analysis and Transformation.

Etim, F. (2018). Metaphysics of Terrorism. Parnnasus, Accepted.

Fanon, F. (1967). Black Skin, White Masks. New York: Grove Press.

Fanon, F. (1982). The Wretched of the Earth. New York: Grove Press.

Fordham, F. (1966). An Introduction to Jung's Psychology. Middlesex: Penguin Books.

Frankl, V. Quotes. https://www.goodreads.com/author/quotes/2782.Victor_E_Frankl

Hegel, F. (1807). Philosophy of the Spirit. Oxford: Oxford University Press.

Hegel, F. (1880). Fragment of a System (Knox, T. M., Trans.).

https://www.marxist.org >hegel

Hegel, F. (1952). Philosophy of Right (Knox, T. M., Trans.). Oxford: Oxford University Press.

Hegel, F. (1956). The Philosophy of History (Sibree, J., Trans.). New York: Dover Publications.

Hegel, F. (1999).Science of Logic (Miller, A. V., Trans.). New York: Humanities Press. https://doi.org/10.1093/actrade/9780198241287.book.1

Heidegger, M. (1956). Hegel and the Greeks. Conference of the Academy of Sciences at Heidelberg. http://www.morec.com/hegelgre 
James, D. (2007). Hegel: A Guide for the Perplexed. London: Continuum International Publishing Group.

Lawhead, F. W. (2002). Voyage of Discovery: A Historical Introduction to Philosophy. New York: Thomson Advantage Books.

Leifheit, P. J. (2012). Hegel on Love. https://www.marxists.org/reference/archive/hegel/works/love/

Moseley, A. (2015). The Philosophy of War: A Peer-Reviewed Academic Resource. Internet Encyclopedia of Philosophy. http://www.iep.utm.edu/war/

O'Grady, S. (2018). This Little-Known Conflict in Nigeria Is Now Deadlier than Boko Haram. The Washington Post. http://www.washingtonpost.com

Oburota, A. (2000). Violence and the Social Order. Bigard Memorial Seminary, Enugu.

Olawale, R. (2018). Opinion: Violence in Nigeria: Causes, Effects, and Solution. http://Ynaija.com

Oxford Dictionary. Violence. https://en.oxforddictionaries.com

Philips, A. (1981). From a Service State to a Paternal State. Inaugural Lecture Delivered at the University of Ibadan, March.

Rousseau, J. (1983). On the Social Contract (Cress, D., Trans.). Indianapolis: Hackett.

Ryan, M. (1984). Marxism and Deconstruction. Baltimore, MD: John Hopkins University Press.

Sartre, J. P. (1992). Notebook for an Ethics (Pellaur, D., Trans.). Chicago: University of Chicago Press.

Stace, W. T. (1955). The Philosophy of Hegel. New York: Dover Publications.

Stumpf, S. E. (1971). Philosophy, History and Problems (5th ed.). New York: McGraw Hill Inc.

Wikipedia. Conflict. https://en.m.wikipedia.org

Wikipedia. Violence. https://en.mwikipedia.org

Wiser, J. (1983). Political Philosophy. A History of Search for Order. Upper Saddle River, NJ: Prentice-Hall Inc. 